\title{
Ammonia production by intestinal bacteria
}

\author{
ANGELA VINCE, A. M. DAWSON, N. PARK, AND F. O'GRADY \\ From the Department of Bacteriology, St Bartholomew's Hospital, London
}

SUMMARY Bacterial growth and the production of ammonia from urea and by deamination of peptone has been examined at various $\mathrm{pHs}$ in both conventional static bacterial cultures and in a continuous cultivation system.

Growth occurred on primary testing of 93 out of 100 strains of aerobic Gram-negative bacteria at pH 5, and 48 out of 50 strains of Esch. coli at pH 4.6.

Hydrolysis of urea by Proteus mirabilis decreased steadily from pH $7 \cdot 2$ to $\mathrm{pH} 5 \cdot 3$; below pH 5.3 little hydrolysis occurred. Ammonia production from peptones by Esch. coli decreased from $\mathrm{pH} \mathrm{7 \cdot 2}$ to $\mathrm{pH} 4 \cdot 6$. Considerable variation was noted in the ability of different strains to produce ammonia. Experiments with cultures containing both Esch. coli and Pr. mirabilis showed that more ammonia was produced at low $\mathrm{pH}$ than was produced by cultures of single organisms.

At low $\mathrm{pH}$ reduction in the count of organisms was not found to be an essential prerequisite for reduction of ammonia formation.

Several workers have found lactulose to be an effective alternative to neomycin in the treatment of hepatic encephalopathy (Fung and Khoo, 1968; Bircher, Scollo-Lavizzari, Hoffman, and Haemmarli, 1969; Elkington, Floch, and Conn, 1969; Ma, McLeod, and Blackburn, 1969; Zeegen, Drinkwater, Fenton, Vince, and Dawson, 1970). Lactulose is a synthetic disaccharide which is not split by intestinal disaccharidases but passes unaltered to the terminal ileum and colon. There it is split by bacterial action into a number of substances, including lactic and acetic acids, with a consequent lowering of the colonic pH.

Ammonia intoxication is an important factor in the genesis of hepatic coma and the beneficial effect of lowering colonic $\mathrm{pH}$ could be due to various factors, acting singly or in combination, causing a fall of portal blood ammonia. One theory is that at a low pH ammonia, which is mainly absorbed by non-ionic diffusion, is almost completely ionized and so not absorbed (Castell and Moore, 1971). This seems unlikely to be the dominant mechanism because there is not a commensurate rise of faecal ammonia (Zeegen et al, 1970). Alternatively, increased growth of acidophilic organisms such as lactobacilli and bifidobacteria could depress the growth of putrefactive, ammonia-producing organisms such as Escherichia coli and Bacteroides spp.

Received for publication 20 December 1972.
However, counts of ammonia-producing organisms do not necessarily fall during lactulose administration (Vince, Zeegen, Drinkwater, O'Grady, and Dawson, in preparation). Another possibility is that a low pH alters bacterial metabolism, so that less ammonia is produced.

Ammonia in the large gut is thought to be derived from either hydrolysis of urea by bacterial, and possibly mucosal, ureases (Wolpert, Phillips, and Summerskill, 1970) or from deamination of proteins and other nitrogenous substrates. Many viable intestinal organisms, eg, bacteroides, bifidobacteria, clostridia, Proteus spp, and Klebsiella spp possess urease activity. Others, notably Esch. coli (the dominant Gram-negative aerobic bacilli in the intestines of most subjects) do not, so that ammonia released by these organisms will be by deamination of substances other than urea. Some organisms will produce ammonia by both mechanisms. O'Grady (1966) showed that the most active of the intestinal organisms in the production of ammonia were Gramnegative aerobic bacilli, eg, Esch. coli, Klebsiella spp, Proteus spp, and Pseudomonas spp.

The purpose of the present investigation was to determine whether production of ammonia by intestinal bacteria was inhibited or reduced at the pHs observed in the caecum during theadministration of lactulose, when a $\mathrm{pH}$-sensitive radiotelemetry pill was used to record the $\mathrm{pH}$. The $\mathrm{pH}$ range found was $3 \cdot 7-6 \cdot 2$ although most readings were less than 5 
(Bown, Sladen, Rousseau, Gibson, Clark, and Dawson, 1972). Bacterial growth and production of ammonia from urea and by deamination of peptone has been examined at various pHs in both conventional static bacterial cultures and a continuous cultivation system. Ammonia production by mixtures of organisms has also been studied, as it is recognized that the behaviour of one organism may be modified by the presence of another in the complex ecosystem of the gut.

\section{Materials and Methods}

\section{ORGANISMS}

Organisms studied were isolated from the colonic effluent of patients who had undergone colonic exclusion and from the small and large bowel and faeces of patients investigated by this department.

\section{CULTURE MEDIUM}

Oxoid nutrient broth (CM67) was used. It was adjusted to the required $\mathrm{pH}$ by the addition of varying amounts of $0 \cdot 1 \mathrm{M}$ citric acid and $0 \cdot 1 \mathrm{M}$ sodium citrate.

SCREENING OF ORGANISMS FOR ABILITY TO GROW AT LOW pH

One hundred organisms were tested: 58 Esch. coli, 16 Klebsiella aerogenes, 14 Proteus mirabilis, and 12 Pseudomonas spp. Aliquots, each of $0.1 \mathrm{ml}$, of overnight cultures of the organisms in nutrient broth were used to inoculate broths at the stated pHs. Plate counts were made initially and after 24 hours' incubation (static) at $37^{\circ} \mathrm{C}$ to determine whether growth had occurred. Continuous growth records of some of these static cultures were also obtained photometrically, using a 12-channel modification (Mackintosh, Watson, and O'Grady, 1973) of the simple turbidity monitoring system described by Watson, Gauci, Blache, and O'Grady (1969).

CULTURE SYSTEMS FOR THE EXAMINATION OF UREA HYDROLYSIS AND PEPTONE DEAMINATION Strains of Esch. coli, which does not produce urease, and Proteus mirabilis, which produces urease, used in these studies were isolated from excluded colonic segments of patients with hepatic encephalopathy.

\section{Static culture}

Four hundred $\mathrm{ml}$ of broth was inoculated with $0.1 \mathrm{ml}$ of a two-hour culture of the organism and incubated at $37^{\circ} \mathrm{C}$. Samples were withdrawn at regular intervals, centrifuged, and ammonia and urea in the supernatant measured either immediately or following storage at $-20^{\circ} \mathrm{C}$ for not more than 24 hours. This had previously been shown not to affect the ammonia content of the samples. Viabie bacterial counts were performed on all samples $\mathrm{a}^{\mathrm{S}}$ described previously (Hamilton, Dyer, Dawson, O'Grady, Vince, Fenton, and Mollin, 1970). Urea was added, where required, immediately before inoculation to a final concentration of 20 or 30 $\mathrm{mg} / 100 \mathrm{ml}$. Control samples for urea and ammonia estimations were taken immediately before, and immediately after, inoculation.

\section{Continuous culture}

The system consisted of a tube containing approximately $35 \mathrm{ml}$ of broth, maintained at $37^{\circ} \mathrm{C}$, and closed with a rubber bung fitted with an inlet connected to a flask containing fresh broth, and an outlet for disposal. A constant volume of fluid was maintained in the tube by connecting the tubes taking fresh medium in and discharge out through the same peristatic pump (Watson-Marlow Ltd, Falmouth). The tube was inoculated with $0.1 \mathrm{ml}$ of a two-hour culture of the organism(s) under test and left to incubate for a further one and a quarter hours before the pump was switched on. The flow rate (around $1 \mathrm{ml}$ per min, depending on the organism) was adjusted to maintain a constant number of organisms $\left(10^{7}-10^{8}\right)$ in the tube. Where required urea was added to the tube when the pump was switched on.

AMMONIA AND UREA MEASUREMENT

Ammonia was estimated as described by Fenton and Williams (1968). Urea was measured by the diacetyl monoxime technique on the AutoAnalyzer.

\section{Results}

THE EFFECT OF PH ON THE GROWTH AND AMMONIA PRODUCTION OF ORGANISMS A hundred strains were tested for their ability to grow at reduced $\mathrm{pH}$. None had been exposed to low $\mathrm{pH}$ in any previous in vitro tests. The results are given in table $\mathrm{I}$.

Fifty-four of the 58 strains of Esch. coli examined grew readily on primary testing at $\mathrm{pH}$. Of 50

\begin{tabular}{lllll}
\hline Organism & \multicolumn{4}{l}{$\begin{array}{l}\text { Number of Strains Showing a Significant } \\
\text { Increase in Count after 24 Hours at } p H\end{array}$} \\
\cline { 2 - 5 } & $7 \cdot 2$ & $5 \cdot 0$ & $4 \cdot 6$ & $4 \cdot 0$ \\
\hline $\begin{array}{l}\text { Escherichia coli } \\
\text { Klebsiella aerogenes }\end{array}$ & $58 / 58$ & $54 / 58$ & $48 / 50$ & $0 / 50$ \\
Proteus mirabilis & $16 / 16$ & $15 / 16$ & - & - \\
Pseudomonas spp & $12 / 12$ & $13 / 14$ & - & - \\
\hline
\end{tabular}

Table I Growth of enterobacteria in nutrient broth at different $\mathrm{pHs}$ 


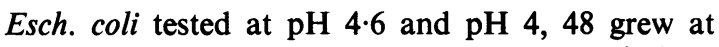
$\mathrm{pH} 4.6$ but none grew at $\mathrm{pH} 4$. None of these organisms could hydrolyse urea.

Forty-two strains of other organisms, ie, Klebsiella aerogenes, Proteus mirabilis, and Pseudomonas $\mathrm{spp}$, were tested for growth at pH 5. One strain of each of the three species failed to grow at pH 5 within 24 hours. All 42 strains split urea in vitro.

Although, as indicated, most of the organisms tested grew at reduced $\mathrm{pH}$, the total viable count reached after 24 hours' incubation at $\mathrm{pH} 5$ was in many cases half, or even less, than that reached at neutral $\mathrm{pH}$. The effect of reduction in $\mathrm{pH}$ on the growth of organisms is more readily seen when a continuous record of the growth curve is examined. The growth curves at various $\mathrm{pHs}$ of one strain of Esch. coli and one strain of Proteus mirabilis are given in figure 1 . From these it can be seen that there is a restricted $\mathbf{p H}$ range over which maximal growth occurs for any given bacterium and a much wider $\mathrm{pH}$ range over which growth still occurs, but at a much slower rate. At low $\mathrm{pH}$, the lag phase before active growth commences is still considerably longer than at neutral $\mathrm{pH}$, and the climax, or total, population achieved is proportionately smaller.

Two organisms (those shown in fig 1a, 1b) were selected for a more detailed study of ammonia production at low $\mathrm{pH}$. However, it is important to realize that although this study is restricted to single strains there is considerable variation in the amount of ammonia produced by different strains of Esch. coli (which do not produce urease), both at neutral and reduced pH (table II). In contrast, three strains of $\mathrm{Pr}$. mirabilis, which produce urease, produced fairly similar amounts of ammonia from cultures containing urea (table II).

\section{AMMONIA PRODUCTION FROM UREA}

Static system, single organism culture

The amount of ammonia formed from urea by a pure culture of $\mathrm{Pr}$. mirabilis decreased steadily with decreasing $\mathrm{pH}$ from $7 \cdot 2$ to $5 \cdot 3$. At $\mathrm{pH} 5 \cdot 3$ the amount of ammonia formed within 24 hours was about half
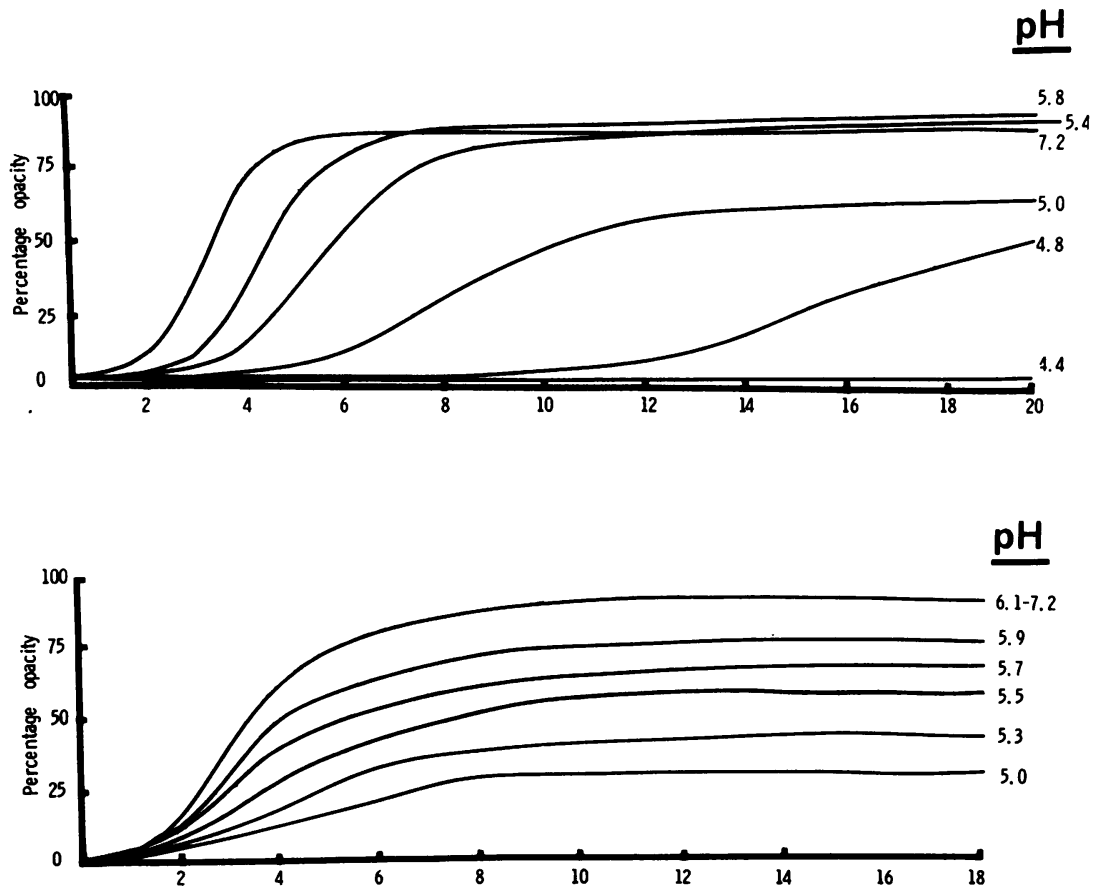

\section{TIME (hours)}

Fig. 1 Growth of Esch. coli (upper graph) and Proteus mirabilis (lower graph) in nutrient broth at different pHs, as shown by increase in turbidity of the medium. 


\begin{tabular}{|c|c|c|c|c|c|}
\hline \multirow[t]{2}{*}{ Organism } & \multirow[t]{2}{*}{ Medium } & \multirow{2}{*}{$\begin{array}{l}\text { Number of } \\
\text { Strains } \\
\text { Tested }\end{array}$} & \multirow[t]{2}{*}{$p H$} & \multicolumn{2}{|c|}{ Ammonia $(\mu \mathrm{g} / 100 \mathrm{ml})$} \\
\hline & & & & Mean & Range \\
\hline E. coli & Nutrient broth & $\begin{array}{l}6 \\
6 \\
6\end{array}$ & $\begin{array}{l}4 \cdot 6 \\
5 \cdot 0 \\
7 \cdot 2\end{array}$ & $\begin{array}{r}2638 \\
3820 \\
12173\end{array}$ & $\begin{array}{r}1200-4040 \\
900-6280 \\
8560-16160\end{array}$ \\
\hline Proteus mirabilis & Nutrient broth $30 \mathrm{mg} \%$ urea & 3 & $7 \cdot 2$ & 30826 & $29200-33200$ \\
\hline Blank determination & Nutrient broth & 10 & $7 \cdot 2$ & 1100 & $920-1300$ \\
\hline
\end{tabular}

Table II Production of ammonia by different strains of Esch. coli, Proteus mirabilis, and medium alone after 24 hours' incubation at $37^{\circ} \mathrm{C}$

that formed at $\mathrm{pH} 7 \cdot 2$ (fig 2). Below pH $5 \cdot 2$ growth occurred (fig 1) but a minimal amount of urea was split.

Once organisms had entered the maximal growth phase at the various pHs the ammonia content of the medium increased steadily with increasing organism count, so that the curves for ammonia production and growth at different $\mathrm{pHs}$ followed similar patterns at $\mathrm{pH} 5 \cdot 3$ and above (compare figs 1 and 2 ).

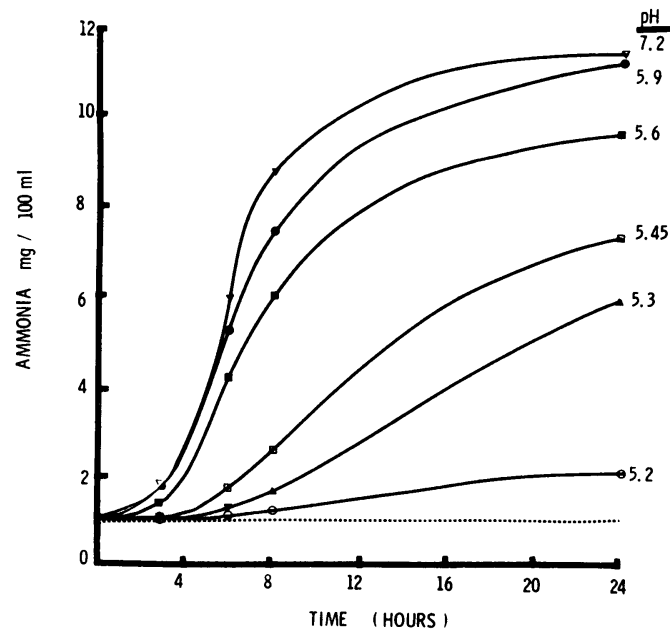

Fig. 2 Ammonia production from nutrient broth containing $20 \mathrm{mg} / 100 \mathrm{ml}$ urea by Proteus mirabilis at different $\mathrm{pHs}$, in static culture. The ammonium content of the medium is indicated by the broken line.

Continuous system, single organism culture

The findings were similar to those obtained in the static system. Urea hydrolysis by Pr. mirabilis was not detected at pH $5 \cdot 3$ or less, the cut-off point being sharply defined (fig 3), most of the ammonia produced below this $\mathrm{pH}$ in the static system presumably being derived from deamination and not from urea hydrolysis. As the $\mathrm{pH}$ was increased from 5.4 to
6.0 urea hydrolysis increased, but above $\mathrm{pH} 6.0$ no further decrease in urea concentration occurred, even when the $\mathrm{pH}$ was increased to $\mathbf{7 \cdot 6}$.

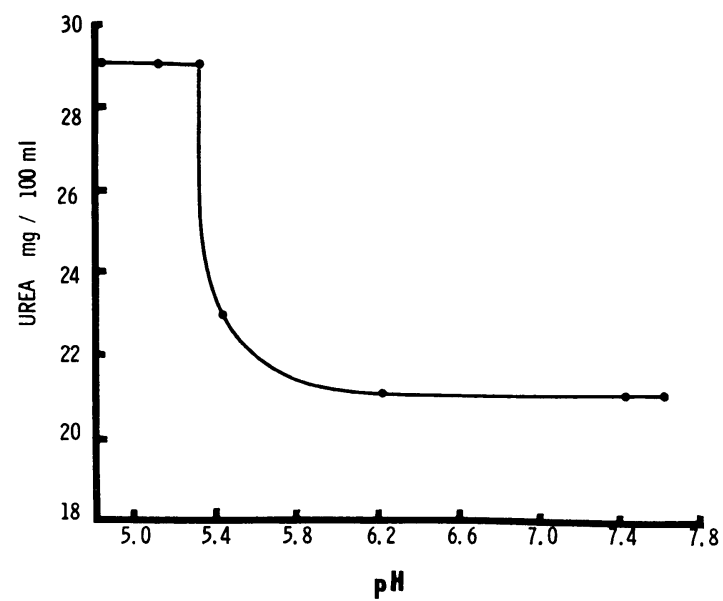

Fig. 3 Hydrolysis of urea by Proteus mirabilis at different pHs during continuous flow culture of the organism in nutrient broth containing $29 \mathrm{mg} / 100 \mathrm{ml}$ urea.

\section{AMMONIA PRODUCTION BY DEAMINATION}

Static system, single organism culture

The ammonia produced by a pure culture of Esch. coli from a solution containing peptones and other protein derivatives decreased steadily with decreasing pH (fig 4). As with the release of ammonia from urea, there was virtually no difference in the amount of ammonia produced over a 24-hour period as the pH was lowered from $7 \cdot 2$ to $6 \cdot 0$. Further reduction in $\mathrm{pH}$ reduced ammonia formation, but not as dramatically as when ammonia was formed from urea by Pr. mirabilis. More ammonia was produced at low pH by Esch. coli than by Pr. mirabilis even when Pr. mirabilis had urea as a substrate. At $\mathrm{pH} 5 \cdot 0$ the amount of ammonia formed in 24 hours was still more than halt the amount formed at $\mathrm{pH} 7 \cdot 2$ and 


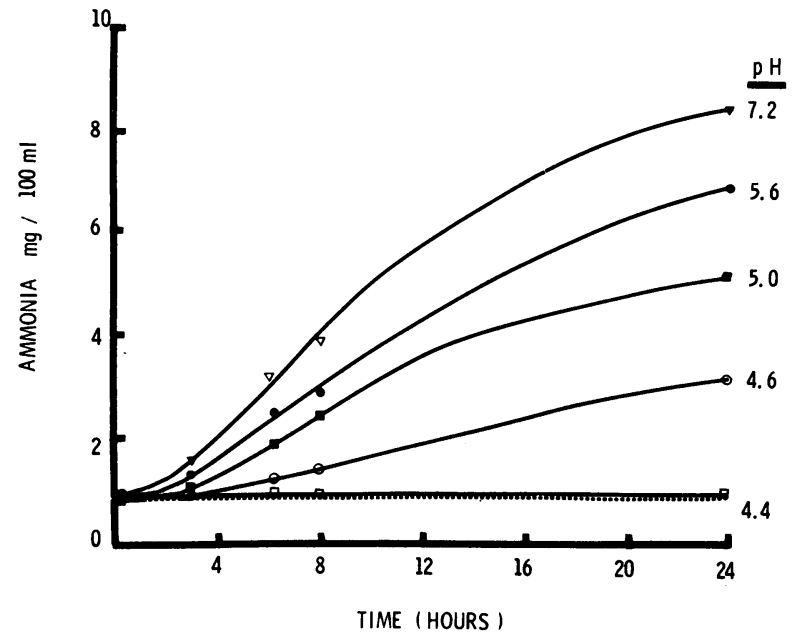

Fig. 4 Ammonia production from nutrient broth by Esch. coli at different pHs in static culture. The ammonium content of the medium alone is indicated by the broken line. even at pH 4.6 small amounts of ammonia were still produced. It was notable that although Esch. coli

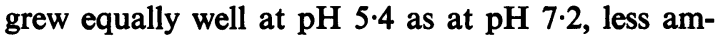
monia was produced at the lower $\mathrm{pH}$. At pH 4.4 and below no growth of organisms occurred (fig 1) and no ammonia was produced.

\section{Continuous system, single organism culture}

The lowest $\mathrm{pH}$ at which ammonia production by Esch. coli was tested in this system was $5 \cdot 2$. In agreement with the static culture results a substantial amount of ammonia was formed.

AMMONIA PRODUCTION BY DEAMINATION AND FROM UREA BY MIXTURES OF ORGANISMS The ability of mixtures of Esch. coli and Pr. mirabilis to produce ammonia at different $\mathrm{pHs}$ from solutions with and without urea was tested over a 24-hour period. At higher $\mathrm{pH}$, ie, 5.6 and above, the picture was similar to that obtained using single cultures of organisms in that ammonia production increased steadily with increasing $\mathrm{pH}$, both from solutions containing urea and from those without it (fig 5). However, in contrast with results obtained from cultures of single organisms, ammonia production from systems with and without urea did not decline, but continued steadily down to $\mathrm{pH} \mathrm{4.7.} \mathrm{The} \mathrm{differ-}$ ence in the amount of ammonia produced from the parallel systems to which urea was or was not added indicates that a small quantity of ammonia was still produced from urea at a $\mathrm{pH}$ as low as 4.7 in a culture containing both Esch. coli and Pr. mirabilis, although none had been produced from urea by a pure culture of the same strain of Pr. mirabilis at such a low pH.

\section{Discussion}

During the administration of lactulose, the $\mathrm{pH}$ of the colon, especially the caecum, drops considerably (Bown et al, 1972). This drop in pH may initially depress counts of some ammonia-producing organisms and so cause a temporary reduction in the amount of ammonia available for absorption. However, acidophilic strains of genera not initially adapted for growth at low $\mathrm{pH}$ soon emerge, which explains why counts of organisms such as Esch. coli, which metabolize lactulose weakly if at all (Hoffman, Mossel, Korus, and Kamer, 1964), are frequently unaffected by lactulose administration.

Whilst at higher pHs reduction in viable count was related to a reduction in the amount of ammonia formed (both from urea and by deamination) the relationship did not hold at low $\mathrm{pH}$, where, although growth of organisms continued, ammonia production was considerably curtailed. These findings confirm that a reduction in the count of ammonia-producing organisms is not an essential prerequisite for a reduction of ammonia formation at low $\mathrm{pH}$.

Considerable variation was observed in the ability of intestinal organisms to produce ammonia, the variation being more pronounced for ammonia production from peptones by Esch. coli than for urea hydrolysis by $\mathrm{Pr}$. mirabilis. Such variation amongst intestinal organisms, combined with the presence or absence of urea-splitting organisms in the gut, might explain the different responses of patients with hepatic encephalopathy to various forms of therapy.

Reduction in ammonia formation following 


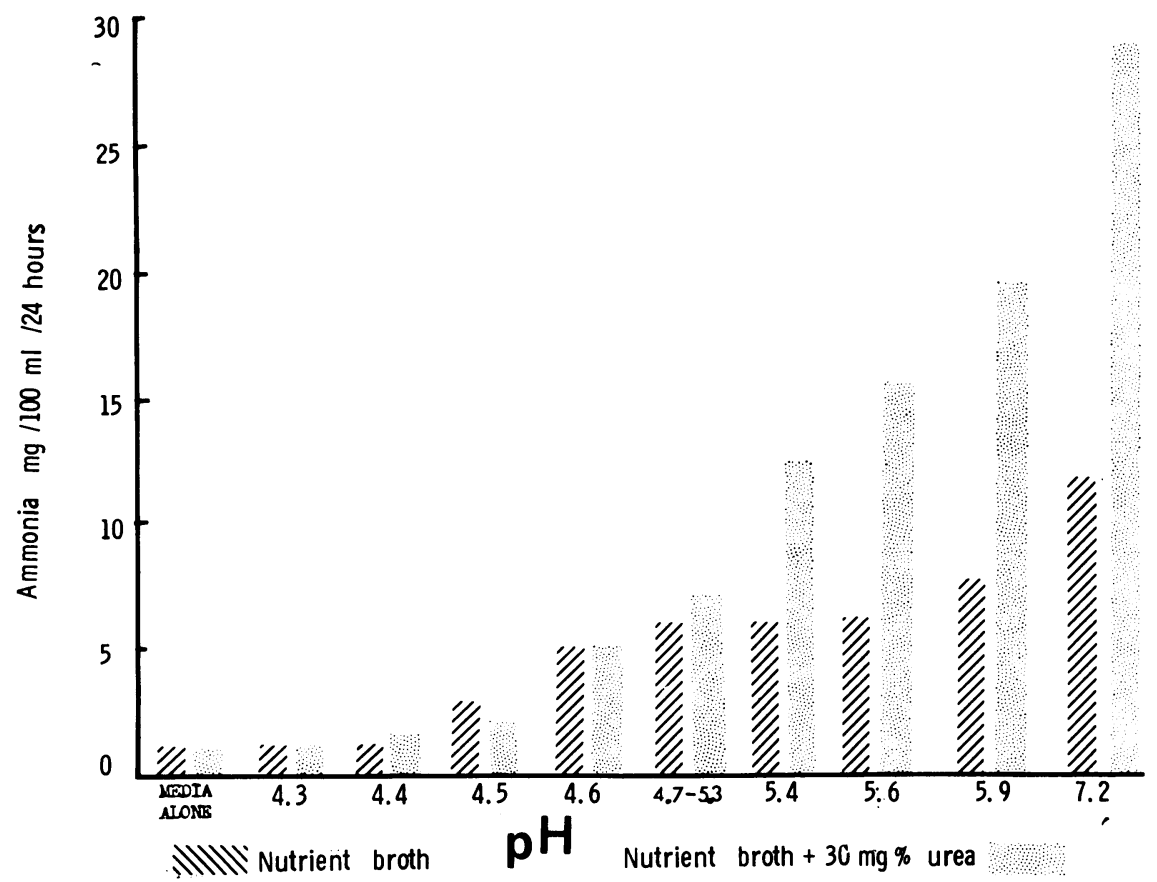

Fig. 5 Production of ammonia from nutrient broth with and without the addition of urea $(30 \mathrm{mg} / 100 \mathrm{ml})$, by a mixed culture of Esch. coli and Proteus mirabilis after 24 hours' incubation.

lactulose therapy must depend to some extent on what constitutes the major source of ammonia in the gut. Decreasing the $\mathrm{pH}$ had a much greater effect on urea hydrolysis than on ammonia production from peptones. This suggests that if urea is ordinarily a major source of ammonia in the intestine, patients colonized by large numbers of urea-splitting organisms should show a more marked reduction in colonic ammonia during lactulose administration than patients lacking such organisms.

Growth conditions in the colon presumably occupy a position intermediate between the extremes of continuous and static culture, which was why both static and continuous culture systems were used in this study. Similar results were obtained from the static and continuous systems, indicating that activity of the organisms was similar in both growth systems. The experiments with mixed cultures indicate that ammonia production is enhanced rather than depressed when more than one organism is present. Cooperative efforts between intestinal organisms have been reported previously (Gustafsson, Midtvedt and Norman, 1968) and there must be numerous opportunities for group activity in the production of ammonia by deamination. A molecule partly degraded by one organism might easily be further degraded by another.

The authors are exceedingly grateful to Dr J. C. B. Fenton for helpful advice on urea and ammonia estimations.

\section{References}

Bircher, J., Scollo-Lavizzari, G., Hoffman, K., and Haemmerli, U. P. (1969). Die behandlung der chronischen porto-systemischen enzephalopathie mit Laktulose. Schweiz. med. Wschr., 99, 584.

Bown, R., Sladen, G. E., Rousseau, B., Gibson, J. A., Clark, M. L., and Dawson, A. M. (1972). A study of water and electrolyte transport by the excluded human colon. Clin. Sci., 43, 891-902.

Castell, D. O., and Moore, E. W. (1971). Ammonia absorption from the human colon: the role of nonionic diffusion. Gastroenterology, 60, 33-42.

Elkington, S. G., Floch, M. H., and Conn, H. O. (1969). Lactulose in the treatment of chronic portal systemic encephalopathy. New Engl, J. Med., 281, 408-412.

Fenton, J. C. B., and Williams, A. H. (1968). Improved method for the estimation of plasma ammonia by ion exchange. J. clin. Path., 21, 14-18.

Fung, W. P., and Khoo, O. T. (1968). Treatment of chronic hepatic encephalopathy with lactulose. Med. J. Aust., 2. 160-163.

Gustaffson, B. E., Midtvedt, T., and Norman, A. (1968). Metabolism of cholic acid in germfree animals after the establishment in the intestinal tract of deconjugating and $7 a$-dehydroxylating bacteria. Acta path. microbiol. scand., 72, 433-443.

Hamilton, J. D., Dyer, N. H., Dawson, A. M., O'Grady, F. W., Vince, A., Fenton, J. C. B., and Mollin, D. L. (1970). Assessment and significance of bacterial overgrowth in the smal bowel. Quart. J. Med., 39, 265-286. 
Hoffman, K., Mossel, D. A. A., Korus, W., and Kamer, J. H., van de (1964). Untersuchungen über die.Wirkungsweise der Lactulese ( $\beta$-Galactosido-Fructose) im Darm. Klin. Wschr., 42, 126-130.

Ma, M. H., McLeod, J. G., and Blackburn, C. R. B. (1969). Long term treatment of portal systemic encephalopathy with lactulose. Aust. Ann.. Med., 18, 117-123.

Mackintosh, I. P., Watson, B. W., and O'Grady, F. W. (1973). Development and further applications of a simple turbidity cell for continuously monitoring bacterial growth. Phys. Med. Biol., in the press.

O'Grady, F. W. (1966). Differences in ammonia production by faecal bacteria of patients with hepatic encephalopathy. Proc. roy. Soc. Med., 59, 1246.

Watson, B. W., Gauci, C. L., Blache, 'L., and O'Grady, F. W. (1969) A simple turbidity cell for continuously monitoring the growth of bacteria. Phys. Med. Biol., 14, 555-558.

Wolpert, E., Phillips, S. F., and Summerskill, W. H. (1970). Ammonia production in the human colon: effects of cleansing, neomycin and acetohydroxamic acid. New Engl. J. Med., 283, 159-164.

Zeegen, R., Drinkwater, J. E., Fenton, J. C. B., Vince, A., and Dawson, A. M. (1970). Some observations on the effects of treatment with lactulose on patients with chronic hepatic encephalopathy. Quart. J. Med., 39, 245-263. 